\title{
Improving Naleni Kain's Clothing Design by Implementing Fashion Trend Forecast
}

\author{
Luri Renaningtyas*, Rika Febriani, Maria Nala Damayanti \\ Fashion and Textile Design, Visual Communication Design \\ Petra Christian University \\ Surabaya, Indonesia \\ *cocolatos@petra.ac.id
}

\begin{abstract}
Naleni Kain is an SME (Small Medium Enterprise from Siwalankerto, Surabaya, which manufactures fabrics with tie-dye techniques. To spread its wings, this SME plans to sell clothing for the young to middle-aged people as its target market. It is important for the fashion business to design clothes according to its target market because trends are one of the consumer's considerations in buying clothes. But that is not necessarily the case, since a trend forecast needs to be synchronized to the target market's taste. This research aims to help Naleni Kain to improve by designing a collection that suits its market based on BEKRAF's 2019-2020 trend forecast. The research nature is qualitative by analyzing the trends of the market in Surabaya, the basic theories of fashion design, and the needs of Naleni Kain, to form the basis for implementing trend forecast into Naleni Kain fashion designs. The result is a mood board design with fashion sketches for men and women aged 1835 years that can be used as a reference for future productions.
\end{abstract}

Keywords-design, implement, trend forecast

\section{INTRODUCTION}

Every year, Paris and New York Fashion Week set up a fashion show of the world-renowned designers as they gained their reputation for the fashion capitals. Almost all big fashion brands will rely on the trend forecast that projects what their market wants. Agencies such as WGSN (World's Global Style Network), Trendstop, Statista.com are the top trend forecast references. Kompasiana.com noted that before the creative industry era, fashion trends in Indonesia were driven initially by famous designers such as Peter Sie and Non Kawilarang. The trend nonetheless tends to imitate the styles in European and Asian countries, especially Japan and Korea, up until now [1]. BEKRAF (The Indonesian Agency for Creative Economy) then also launched an Indonesian trend book which is expected to be a guide for the creative industry in Indonesia, including fashion. Singularity is the main theme for 2019-2020, but it is still felt that there are many who do not understand it. Therefore, BEKFRAF conducted outreach in various regions.
However, since BEKRAF was deactivated after the inauguration of the President in October 2019, and later merged into a new ministerial board, further socialization for the fashion creative industry at lower levels such as SMEs or those on a household scale would certainly be needed.

As for Lilik Solikati, the owner of Naleni Kain, an SME running a fashion business, is a case study that fits with the phenomenon stated above [2]. She hopes to be able to 'read' her market, as she aims young to middle-aged people aged 1835 years old in Surabaya that goes along with the brand image of Naleni Kain. The research is to implement trends to a design, how the global trends can finally be reinterpreted with the local language so that it can easily fit into a particular market. This design process eventually shapes the way of thinking of a designer and to Naleni Kain, in particular, to be updated every time they design a product.

This research method is qualitative by visually analyzing trend forecasts within the theory of fashion design elements and principals, including colors, silhouettes, and pattern designs. Description of how the market responds to fashion as a lifestyle especially when wearing naturally dyed garments such as tie-dye and shibori enriches the analysis. It formulates eight fashion design sketches: four designs for men and four for women. These designs are considered as an instrument to gain a better chance of sales.

\section{LITERATURE REVIEW}

\section{A. Naleni Kain}

Naleni Kain's specialty is jumputan or tie-dye using Remasol dyes. This SME was established in June 2019, initiated by Lilik Solikati and a design student, Cornelli Kwanda, on her final project [3]. Naleni Kain has made several collections such as long shrugs, formal apparel for women, etc. (see figure 1). 


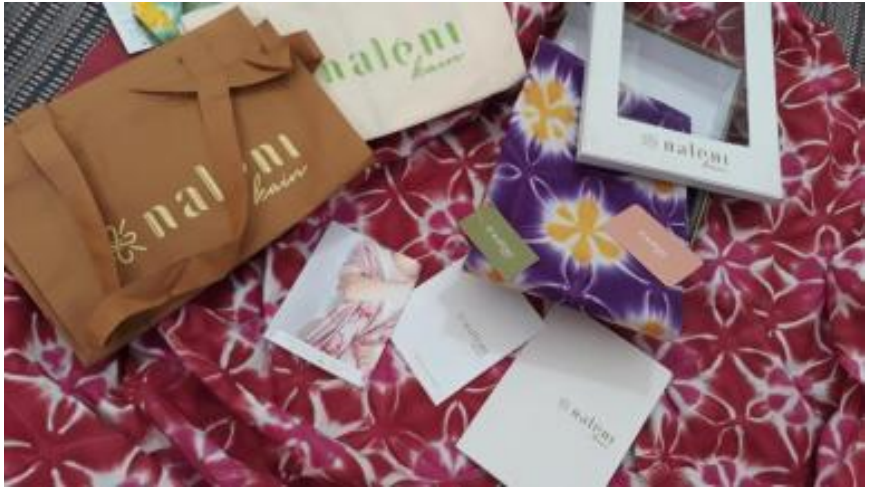

Fig. 1. Naleni fabric branding: paper bags, packaging boxes, brochures, catalogs, price tags. Photo by: Luri Renaningtyas.

\section{B. The 2019-2020 BEKRAF Forecast}

BEKRAF's 2019-2020 Trend Prediction is Singularity with a hypothesis predicting that the discovery of super artificial intelligence will suddenly trigger the growth of technology that surpasses all human intelligence. This becomes a critical point for questioning the future of human supremacy on earth [4]. There are four interesting themes that represent Singularity for Indonesia in 2019-2020, namely:

- Exuberant. A dynamic and intelligent human character and a positive spirit. The basic characters of this theme are relaxed, friendly, a little "nerdy", but still stylish and cute. A life that is inseparable from digital technology embraces cultural reconciliation in music, entertainment, and art, which is visualized with color graphics, street art, comics, and cartoons. Inspired by the Asian-American subculture that spreads throughout the world, especially Asian countries, including Asian Tap-Rap music, which made Indonesian rapper Rich Bryan soar in the international entertainment business.

- Neo Medieval. There is something about Medieval epoch that is so captivating in the modern and high-tech world of which the romantic narrative of the history of this era is urgently needed to reassure one from the current political and cultural situation. Medieval takes form only as a celebration within the wardrobe, with the touch of futuristic and high-tech features. It pushes our imagination and creativity to live in the historicalfuturistic style.

- Svarga. A theme that represents humanity emphasized the cultural idea, strengthen the human side of the Singularity concept mentioned above. Svarga or "Heaven" in Sanskrit, describes the spiritual approach between humans. Svarga is a symbol of mankind that unites and collaborates, giving generosity and knowledge in exchange for happiness creating heaven on earth, reducing damage and social illness caused by humans and their ego throughout the time. The design underlines the value of traditions and local wisdom of craftsman; whose existence supports cultural preservation.

- Cortex. It represents the basic system that disrupts life in the Singularity. The algorithms of social media we use to dictate our tastes, tendencies, and even the way we think. Meanwhile, we still believe that whatever is in our heads is a pure result of thought processes. There are hypotheses that tend to frame artificial intelligence or AI as a way to synthesize humans and machines, which would transform us into superstars. In the design development process, it has been proven that AI not only functions as an auxiliary for a designer but can also be a designer itself. Though there have been pros and cons, AI can also mean hope for a better world. This theme describes AI as an external neocortex for humanity, which can be used as a tool for exploration, materials, and research media. AI opens new horizons to a vision, form, and material world.

\section{Trend and Fashion}

Trends are closely related to fashion, but in order to understand them, it is necessary to know the definition of design and style. In the context of fashion, the design is a synthesis of fabric, clothing silhouettes, and other details that can be found in fashion objects, that can differentiate itself from others. A trend is a movement towards something. Meanwhile, the style according to Sproles and Burns is a display with distinctive characters from several similar objects in the same group or category [5]. For example, in the skirt category, there are models of pencil skirts, miniskirts, pleated skirts, and A-line skirts. Other examples of popular styles are below:

- Hippies were popular in the 1960s and 1970s, the anti-mainstream movement against American life projected on the way they fashion themselves: long hair and casual, wore an unconventional dress, with "psychedelic" colors. Men grew beards wore sandals and beads as well as women. They favored long flowing flowery dresses paired with rimless glasses. This style channels the Svarga theme.

- In the 1970s a radical youth movement called Punk or "Public United Not Kingdom" emerged. The Punk ideology of anti-mainstream projected through their way of life and how they look, generated by rock and roll music. Sex Pistols was the most popular band at that time. On the other hand, British fashion designer Vivian Westwood became strongly associated with Punk when she designed a provocative collection of a tartan skirt, leather jacket, iconic chain-detailed pants, and ripped tops with shocking graphics and quotes, shouted out the same 'message' of protest [6]. As Daniar Setyanto explained in his journal, these punkers dyed their mohawk hair, and wear boots, tattooed, and pierced their body with "Do it 
Yourself" items such as safety pins, studded bracelets [7]. The Punk's rebellious vibe might be adopted in Neo Medieval theme.

- The war setting of military look, created the necessity to imitate the nature or to survive from the enemy, as soldiers wearing uniforms or combat gear in camouflaging color. During 1856 a British designer Burberry promoted the trench coat that protected the body from extreme weather. Along with cargo pants with many pockets, flight jackets and hooded parkas are all the code for the ultimate military style [8]. These codes are also like those that appear in the Neo-Medieval theme.

- Harajuku is a district around Tokyo's Harajuku Station, between Shinjuku and Shibuya on the Yamanote Line. It is the epicenter of style and trends of Japanese youth but it also offers tourists a shopping experience and some historic sights. Harajuku is aggressively stylized, excessively accessorized from many inspirations such as designers, idols, music, illustrators, and western cultures [9].

- Futurism, the style that emphasizes dynamism, speed, power of the machine, and modern life [10]. Paintings such as cubism and constructivism visualized the spirit of futurism. In 1918 a unisex jumpsuit called the tuta introduced by futurist fashion designer Thayaht, that soon became a predecessor of "sportswear" today. Futurism's concept after the Giacomo Balla's manifesto of futuristic clothing should appear illuminating and phosphorescent evolved within the setting of space exploration in the 1960s [11]. Minimalist and sleek clothing constructed with geometric shapes. Synthetic fabrics, plastics, and metals into clothing for a futurist effect. Today's vision of the future is shaped by technology such as mechanized clothing capable of instantly changing shape. Sustainable fashion is also a new focus on futuristic fashion. Low-maintenance synthetics, recycled cotton, and skins from managed populations of animals. This vision is reflected in Cortex as well.

\section{An Overview of The Basics of Fashion Design}

The data explained above is then synthesized to a design concept. This process of visualizing the concept is called implementation. It requires an understanding of the basic theories of fashion design, although not all theories are used later. The theory is based on "The Fashion Design Manual" by Pamela Stecker. According to Stecker, to produce a good design a designer must apply elements and principles of design described with figure 2 [12].
The application of design elements and design principles in a garment lies in the structures and decorations. They are seams, pleats, underlines of clothing, clothing openings, etc., while in decoration are sequins, bias tape, embroidery, etc. The design of a garment can be said to be successful if the garment is functional, with its structure and decoration that also interact harmoniously [13]. Color theory is used to help visualize verbal concepts in the existing trend forecast. Color theory will emphasize the visual effects of color and the color wheel. This underlies the goal of determining which colors are young people think will be liked. Meanwhile, the shape and silhouette theory will help visualize the cut shape model that is considered suitable for the taste of the market.

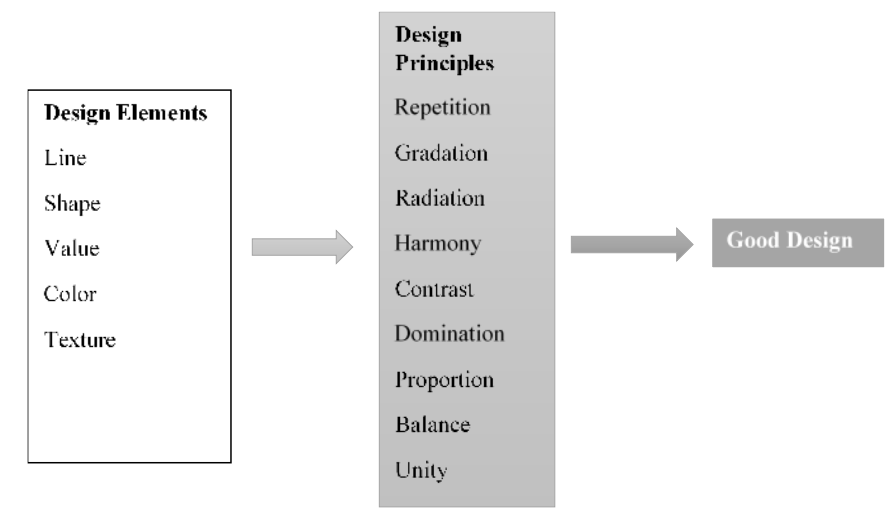

Fig. 2. Schematic of how elements and principles of design work. Source adapted from The Fashion Manual p. 68.

\section{E. Consumer Insight in Surabaya Related to Tie-Dye and Apparel}

There is an interesting phenomenon in Surabaya related to fashion, especially batik. The term batik is evenly distributed into fabrics that are dyed both artificially and naturally, regardless of the working technique. UNESCO's definition of batik is a technique of drawing on cloth using canting and wax which is heated and then dyed, to go through the next process to become batik cloth. Unlike Jumputan or Sasirangan (from South Kalimantan), the dyeing technique is tied, thus called tiedye. This wrong term is not only common in the public but also the craftsmen and the sellers. This tie-dye cloth is always sold together with batik. People aged 18-35 years will buy them at batik shops in department stores and already have a strong perception that tie-dye is a variation of batik. Their response to such fabrics is different from when buying ordinary apparel products. According to Embran Nawawi, Surabaya's fashion designer whose expertise in understanding its people, these young people in Surabaya are aware of the trends that are happening around them, as a matter of fact, they are quite stylish, too. It is just that they are stuck in the paradigm of tiedye and shibori that are sold together with batik, and that they are only suitable for certain formal occasions. In the end, they only have one or two pieces in their wardrobe because there aren't many choices. 
Interviewed on another occasion, Embran also expressed his observations about tie-dye or natural dye, which is a niche market with only certain people who like it, especially when the tie-dye trend has passed. However, that does not mean that this fact becomes an obstacle for designers to adopt tie-dye as their design idea. There is always a chance for tie-dye to become popular again. It really depends on the packaging, and one of which is by following the trend. However, a trend cannot be adopted as it is, let alone be able to be accepted by the audience. The market in Surabaya compared to Jakarta, chooses styles that are popular and mainstream. Young people look up to K-pop idols and adopt their style. They also wear tshirts and jeans, and when going to parties they often choose dresses. Most of them shop for clothes at the mall looking for fast fashion brands with styles that are mainstream and popular. Often, they just see what the retails have to offer once they get into the store. Therefore, Embran explained window displays, certain arrangements on clothing retail shelves, and styling between apparel and accessories will help communicate the ideas of the designer to the audience. It is easier to understand what style is, or what kind of look it is when a collection is shown on a mannequin from head to toe, complete with accessories and props, rather than displaying them separately [14].

\section{RESEARCH METHODS}

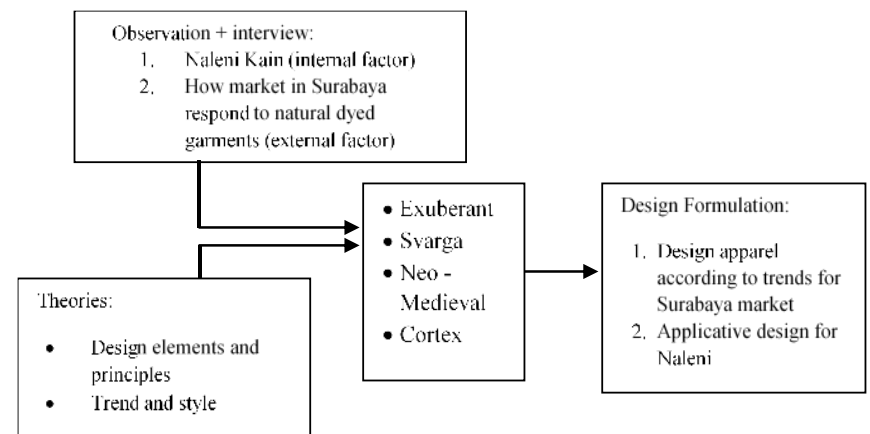

Fig. 3. Research method and analysis scheme.

The data above were analyzed qualitatively to make a concept, as a process of design implementation. The BEKRAF's trend forecast is used as a design reference, and by considering two factors, internal and external, the trends are interpreted and implemented into eight designs. The internal factors are those that would affect the concept, such as the need for the market and its product development for the long term; how to create an applicative design for Naleni Kain that is easy and affordable to produce. While the external factor is how the market in Surabaya respond to fashion, in particular, tie-dye based on observations in several malls in Surabaya and interviews with fashion designers that are previously described in section 2. The implementation is also based on the principles and elements of fashion design as well as theories about trends and styles in order to generate good design as explained in figure 3 .
The visual analysis is done by separating each trend theme into a basic item and style. It is easier to describe their main characteristics in order to be adjusted to Naleni Kain's design concepts.

TABLE I. ANALYSIS RESULTS

\begin{tabular}{|c|c|c|c|c|c|}
\hline \multirow{2}{*}{ Theme } & \multicolumn{2}{|c|}{$\begin{array}{l}\text { BEKRAF } \\
\text { Trends 2019- } \\
2020 \\
\end{array}$} & \multicolumn{3}{|c|}{$\begin{array}{l}\text { Implementation (design } \\
\text { formulation) }\end{array}$} \\
\hline & $\begin{array}{l}\text { Basic } \\
\text { item }\end{array}$ & Style & $\begin{array}{c}\text { Basic } \\
\text { item }\end{array}$ & $\begin{array}{c}\text { Elements and } \\
\text { Principles of } \\
\text { Design } \\
\end{array}$ & Style \\
\hline $\begin{array}{l}\text { Exuberant } \\
\text { Adjective: } \\
\text { Cheerful, } \\
\text { Strange, } \\
\text { Passionate, }\end{array}$ & $\begin{array}{l}\text { Shirt, } \\
\text { T's and } \\
\text { long } \\
\text { shrugs }\end{array}$ & $\begin{array}{l}\text { Hara } \\
\text { juku }\end{array}$ & $\begin{array}{l}\text { Over- } \\
\text { sized } \\
\text { shirts, } \\
\text { kimonos, } \\
\text { skirts, } \\
\text { they can } \\
\text { be worn } \\
\text { in any } \\
\text { occasions }\end{array}$ & $\begin{array}{l}\text { The cutting is } \\
\text { unusual and } \\
\text { asymmetrical. } \\
\text { The H and A } \\
\text { silhouette. } \\
\text { A Repetitive } \\
\text { and large- } \\
\text { sized } \\
\text { geometric } \\
\text { shibori motif. } \\
\text { Rich in color } \\
\text { and motif }\end{array}$ & $\begin{array}{l}\text { Hara- } \\
\text { juku }\end{array}$ \\
\hline $\begin{array}{l}\text { Svarga } \\
\text { Adjective: } \\
\text { Colorful } \\
\text { Spiritual } \\
\text { Cheerful }\end{array}$ & $\begin{array}{l}\text { Long } \\
\text { shrugs, } \\
\text { H } \\
\text { silhoue } \\
\text { tte with } \\
\text { loose } \\
\text { materi- } \\
\text { al }\end{array}$ & $\begin{array}{l}\text { Hip- } \\
\text { pies }\end{array}$ & $\begin{array}{l}\text { Multi- } \\
\text { function- } \\
\text { al blouse } \\
\text { and long } \\
\text { shrugs } \\
\text { for } \\
\text { formal } \\
\text { and } \\
\text { casual } \\
\text { events }\end{array}$ & $\begin{array}{l}\text { A loose and } \\
\text { lightweight } \\
\text { piece of a } \\
\text { silhouette. } \\
\text { Tie-dye } \\
\text { motifs are } \\
\text { integrated } \\
\text { with weaving. } \\
\text { Rich in color } \\
\text { and motif }\end{array}$ & $\begin{array}{l}\text { Hip- } \\
\text { pies }\end{array}$ \\
\hline $\begin{array}{l}\text { Neo } \\
\text { Medieval } \\
\text { Adjective: } \\
\text { Masculine } \\
\text { Heavy } \\
\text { Heroic }\end{array}$ & $\begin{array}{l}\text { Fit on } \\
\text { the } \\
\text { body } \\
\text { or } \\
\text { loose, } \\
\text { I or H } \\
\text { Silhoue } \\
\text { tte }\end{array}$ & $\begin{array}{l}\text { Medi } \\
\text { eval, } \\
\text { Punk }\end{array}$ & $\begin{array}{l}\text { Blazer } \\
\text { and long } \\
\text { shrugs }\end{array}$ & $\begin{array}{l}\text { I and H } \\
\text { silhouette. } \\
\text { Decoration of } \\
\text { different } \\
\text { materials } \\
\text { such as } \\
\text { patchwork } \\
\text { and topstitch } \\
\text { portrays } \\
\text { dystopia. } \\
\text { Details of the } \\
\text { folds (pleats) } \\
\text { like a uniform } \\
\text { channeling an } \\
\text { idea of } \\
\text { marching } \\
\text { soldiers }\end{array}$ & $\begin{array}{l}\text { Mili- } \\
\text { tary }\end{array}$ \\
\hline Cortex & $\begin{array}{l}\text { Shrug, } \\
\text { dress }\end{array}$ & $\begin{array}{l}\text { Futur } \\
\text { istic }\end{array}$ & $\begin{array}{l}\text { Sweat- } \\
\text { shirt and } \\
\text { long } \\
\text { shrugs }\end{array}$ & $\begin{array}{l}\text { Decoration on } \\
\text { the garment } \\
\text { makes it look } \\
\text { futuristic. E.g. } \\
\text { Sequin and } \\
\text { patchwork. } \\
\text { Organic and } \\
\text { geometric } \\
\text { motif shaped } \\
\text { tie-dye or } \\
\text { shibori }\end{array}$ & $\begin{array}{l}\text { Art } \\
\text { Nou- } \\
\text { veau, } \\
\text { sporty } \\
\text { (loose } \\
\text { silhou } \\
\text { ette } \\
\text { gives a } \\
\text { dyna- } \\
\text { mic } \\
\text { impres } \\
\text { sion) }\end{array}$ \\
\hline
\end{tabular}

Every adaptation is based on the two factors and the theories in figure 3. For example, describing that Cortex has 
basic items such as a long shrug and show similarity with futuristic style, will definitely give the designer a more vivid picture of how it should look like and a strong base to start off with.

\section{RESULTS}

Naleni Kain has a desire for improvements, hence instead of solely patronizing on fashion trends, the designs here were also made by considering economic factors and consumer preferences. Thus, the trend should be reinterpreted in order to suit the economic factors and consumer preferences. The following are mood boards as results of BEKRAF fashion trend 2019-2020 implementation in the designs.

\section{A. Exuberant}

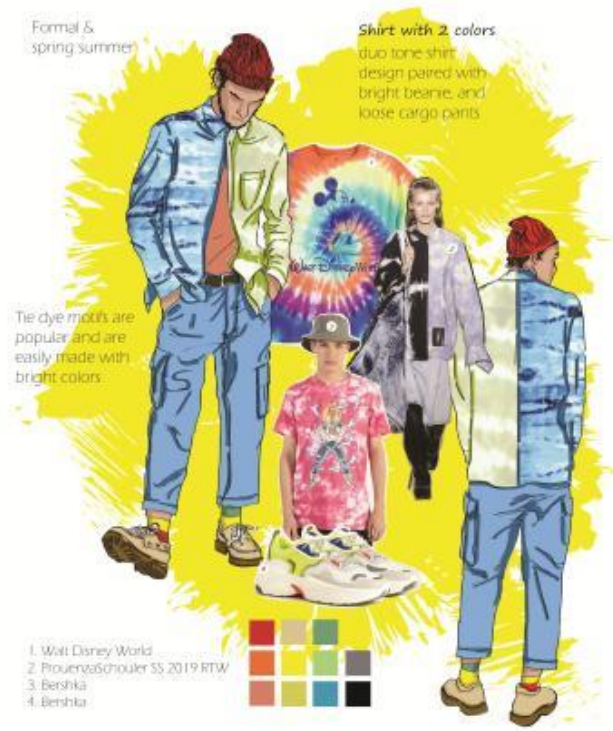

Fig. 4. Shirt design based on the Exuberant theme.

The Exuberant mood board is based on adjectives such as energetic, optimist, positivity, and dynamic (see figure 4). These are represented in bold color scheme matched with the style Harajuku. The basic characteristics are shown in asymmetrical silhouette and two colors in one garment. The women's kimono design tends to be in neutral tones, using beige and gray in its collar. The collar shape is in the New Age Zen theme, in harmony with asymmetrical wrap-skirt. Kimono material is shibori made by wooden clamp technique resulting in a large easy-to-made pattern. Meanwhile, tie-dye is used for the skirt pattern incorporated with plain blue fabric. Kimono and wrap skirt are matched with a white shirt and bold colored socks to achieve a geometric, dynamic, and optimistic impression in a Japanese way. The men's shirt comes in twotones as well, blue and green in a tie-dye pattern. The shirt can be converted into long shrugs by using a t-shirt as inner matched with jeans cargo pants, a red beanie hat, colorful socks, and a pair of boat shoes. The shirt comes in S, M, L gradings. The overall look should be nerdy, odd, and retro.

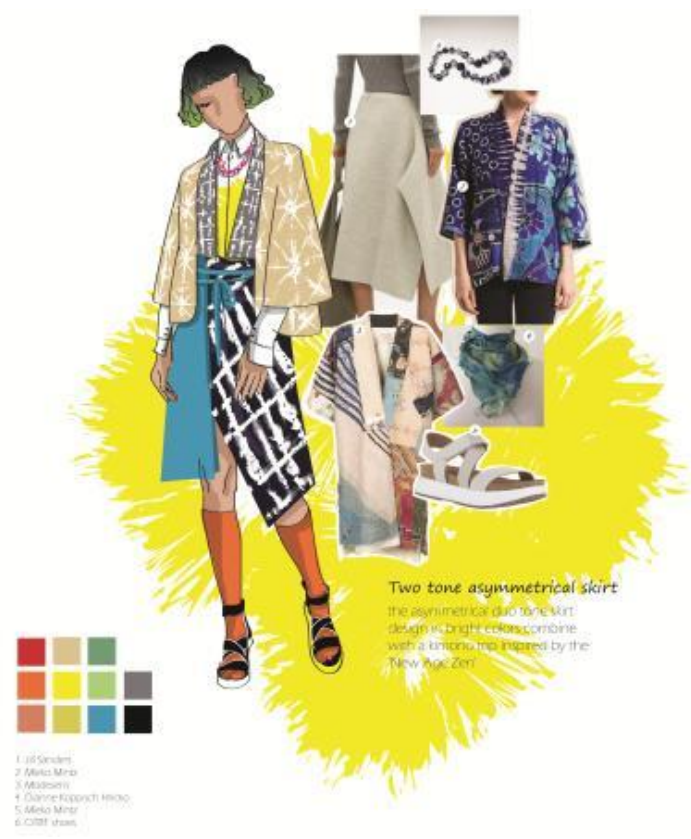

Fig. 5. Kimono and skirt design based on the Exuberant theme.

These are the production calculations: the women's kimono takes up 2 meters of fabric, added with another meter for its collar. Wrap skirt needs 2 sheets in 1.5 meters each (see figure 5). The men's shirt uses 1.5 meters of fabric for each side. All should be added with the tie-dye making costs. The price range for the women's kimono is IDR 300,000 and IDR 250,000 for a skirt. The men's shirt is priced in IDR 300,000.

\section{B. Svarga}

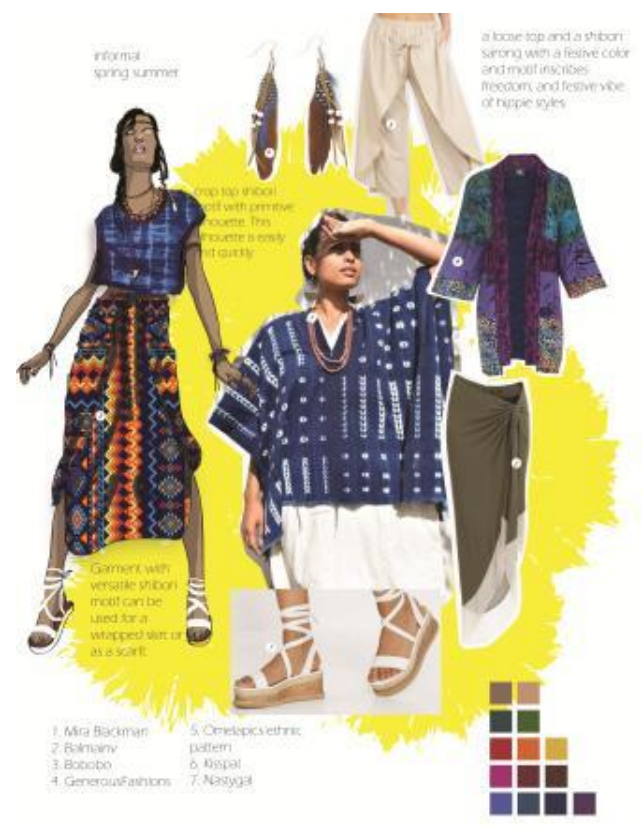

Fig. 6. Design top based on the Svarga theme. 
Svarga could be translated into relaxing, freedom, and earthy (see figure 6). The overall appearance is similar to the hippies or boho styles of the 1970s. Vibrant motifs, colliding shapes, and colors, loose silhouettes of clothing, and light, loose fabrics are key to the look. However, the Svarga design here is kept simple and the colors are not flashy. For women, the top design is in a tie-dye pattern in indigo blue with a square silhouette. The sewing pattern for this loose-rectangular silhouette is easy to make, thus economical and efficient and will speed up the production time. 1.5 meters of cloth is needed for the top. The price is around IDR 199,900. Size availability would be in S, M, L.

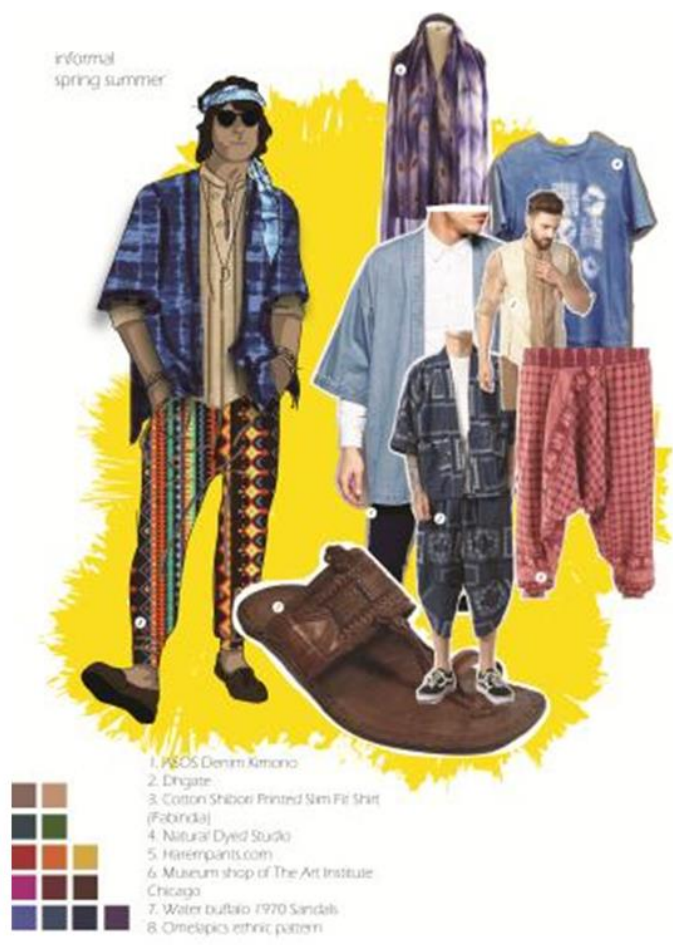

Fig. 7. Kimono design based on the Svarga theme.

The men's kimono design is decorated with tie-dye patchwork occupying leftovers from tie-dye clothing. Patchwork finishing uses red thread to highlight the patch (see figure 7). This kimono may become a long shrug for a shirt or a koko as its inner. To make the hippies look more visible, the kimono is combined with harem pants along with tie-dye headband accessories and casual moccasin shoes or sandals. Kimono would require 2 meters of fabric and should sell for IDR 250,000. Size available only in F. Both men's and women's designs are suitable for casual occasions such as going to the mall or just hanging out with friends and colleagues.

\section{Neo-Medieval}

This theme looks heavy, dark, and a bit masculine. The apparel design outcome is a women's long shrug and a men's blazer. The women's long shrug can be combined with hijab and is suitable for all occasions, but the men's blazer tends to fit in formal events. The long shrug's detail is simple geometric embroidery on a shibori pattern, plus a rayon or supernova pocket decoration; two on the front, and one right in the middle of the back. Then there are details such as a pleats box skirt on the hemline, referring to Armory style that displays elements of clothing such as heroes or warriors in futuristic films that seem to be used to hide weapons other than as decorations. The long shrug is combined with leather pants and sneakers. The selling price for the long shrug is IDR 250,000.

The design for the men's Neo-Medieval theme is a denim blazer with a collar with a different fabric. In order to make the Neo-Medieval look more visible, this blazer is styled with a sweatshirt, cargo pants, and boots. The selling price is around IDR 399,000.

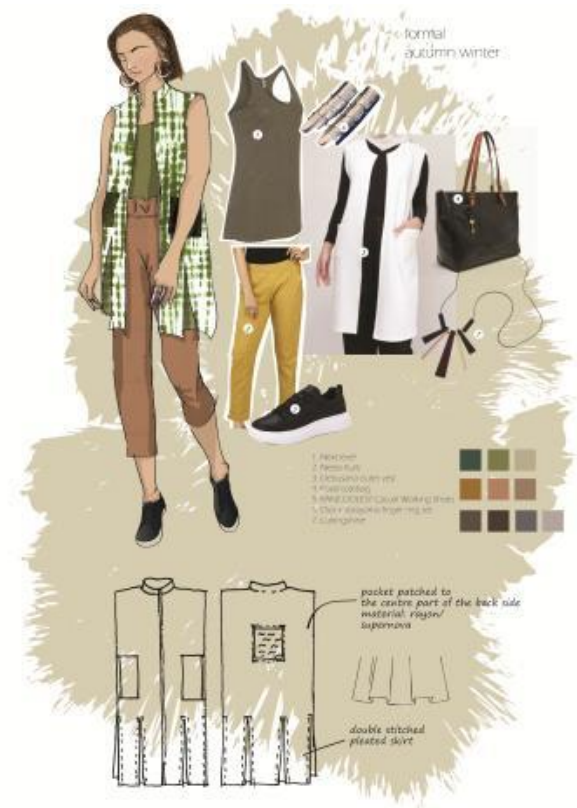

Fig. 8. Long shrugs based on the Neo-Medieval theme.

\section{CONCLUSION}

Naleni Kain is a fashion start-up business selling formal and semi-formal tie-dye and shibori clothing (see figure 8). In the fashion business, the following trends are an important key to attract consumers. The problem is that world fashion trends cannot be directly applied to apparel design, even trends that have been adopted, such as those from BEKRAF also need adjustments when they are to be used as design references. Trend depends on the community's socioeconomic and cultural conditions in a certain period. Therefore, it must be reconfigured to find the unique design components that suit the community.

In this case, Naleni is targeting the target market for Surabaya youths and middle-aged people aged 18-35 years. They know about the present trends, yet they prefer designs that are more functional and general, such as choosing t-shirts 
and jeans for campus outfit, or casual shirts and pants for working. Tie-dye and shibori clothing are more often seen to be worn for formal events, and not many modifications and options are available in the market. So, in Surabaya, both types tend to have niche markets (see figure 9).

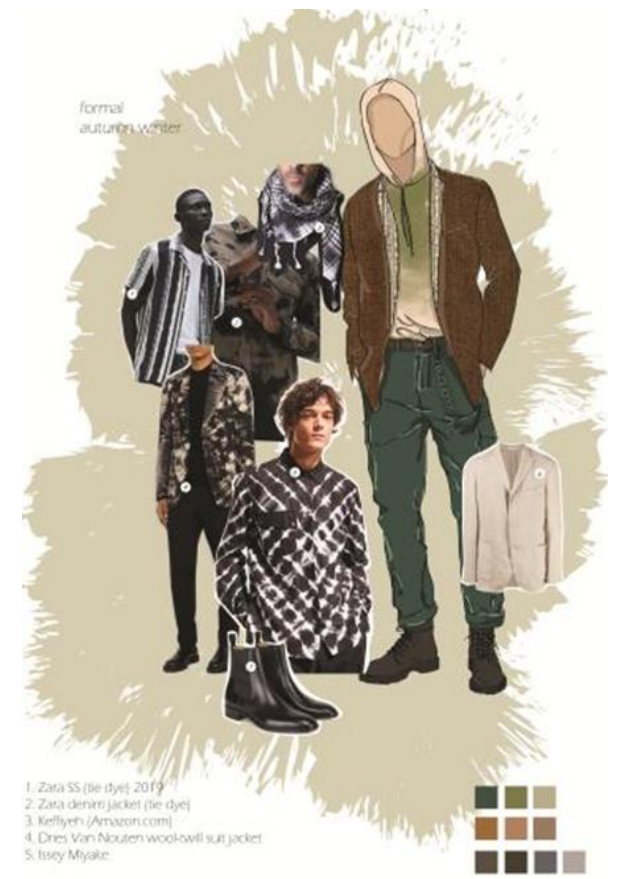

Fig. 9. Blazer based on Neo-Medieval theme.

Referring to the phenomenon, the BEKRAF trend forecast underwent adjustments as stated in the analysis chart in section 3. Even the final designs may seem like they do not refer to any trends, but the implementations have considerably suited the consumers. For example, if a consumer likes a simple fashion style, and then introduced to a trend theme such as Exuberant which looks striking, she might find it difficult to accept. As a solution, the Exuberant theme is simplified into solely kimono and skirt. The spirit of New Age Zen is adopted in the silhouette of kimono designs and asymmetrical skirts with neutral color choices such as beige, gray, and blue, so not all colors are used and not all items have to be the same. Kimono designs with the theme of Svarga, and blazers with the theme of Neo Medieval are all made in consideration of Naleni's limited production capabilities as an SME. However, the overall design must have appearance matched with the theme. They are displayed in a coherent form (styling) in the mood board, showing the head to toe design, looks more appealing than if the design was only displayed in a piece.

A trend implementation would make it easier for SMEs to make clothing that have their own uniqueness and match their market's preference. Such clothing design shall have higher likability as an alternative to mass-produced, fast fashion products in Surabaya. However, as scientific research takes time, the trend discussed here has a short validity period (typically one year). As the research is ongoing, the trend is also ongoing or even out of date, so it would be better to discuss trends for the next two to three years.

\section{ACKNOWLEDGMENT}

We are highly indebted to Petra Christian University for the support prior to the research content. We would like to express the deepest appreciation to Lilik Solikati for having shared with us her thoughts and experience in Naleni Kain, and for trusting and optimistic to us. An appreciation also goes to Embran Nawawi for invaluable insight sharing. Also, to Ani Fardiani for the helpful contributions for the sewing patterns. Many thanks to Rika Febriani and Maria Nala as a solid team, working together we finally carried out our project. Finally, we would address our deepest gratitude to Petra's Research Institution and Community Service, which without the supervision and funding, this research would not have been possible to complete.

\section{REFERENCES}

[1] A. Mega, "Gaya Hidup". 2017. [Online]. Retrieved from Kompasiana: https://www.kompasiana.com/annisamega/588321f3cc92731105931d89/ perkembangan-trend-fashion-di-indonesia?page $=$ all

[2] L. Solikati, Interview to the owner of Naleni Kain. (L. Renaningtyas, \& R. Febriani, Interviewers), Surabaya: Siwalankerto, 2019.

[3] C. Kwanda, Perancangan Visual Branding Sebagai Pendukung Promosi Produk Batik Ikat Celup UMKM Siwalankerto di Surabaya Surabaya: Universitas Kristen Petra, 2019.

[4] BEKRAF. Tren. 2019. [Online] Retrieved from trendforecasting.id: https://trendforecasting.id/singularity-section/tema-impulse-book-2

[5] G.B. Sproles and L.D. Burns, Changing appearances: Understanding dress in contemporary society. Fairchild publications, 1994.

[6] P. Grossman, Clothing, Jewelry, and Personal Adornment. 2020 [Online] Retrieved from Encyclopedia: https://www.encyclopedia.com/sports-and-everyday-life/fashion-andclothing/clothing-jewelry-and-personal-adornment/punk

[7] D.W. Setyanto, Makna dan Ideologi Punk. Andharupa, 51-58. 2015.

[8] J. Hopkins, Military Dress and Uniforms. In J. Hopkins, Basic Fashion Design 07: Menswear (pp. 26-29). Laussane: AVA Publishing. 2011

[9] T. Godoy and I Vartania, Harajuku Made Me Do It. In T. Godoy, Style Deficit Disorder: Harajuku Street Fashion - Tokyo (pp. 10-13). San Francisco: Chronicle Books. 2007.

[10] N. Pioch, Futurism. 2002. [Online] Retrieved from ibiblio.org: http://www.ibiblio.org/wm/paint/glo/futurism/

[11] E. Braun, "Futurist fashion: Three manifestoes". Art Journal. Mar 1;54(1):34-41. 1995.

[12] P. Stecker, "Chapter 6: The Principles of Design. In P. Stecker, The Fashion Design Manual (pp. 67-81)". South Yarra: Macmillan Education Australia PTY LTD. 1999.

[13] P. Stecker, Chapter 4: The Elements of Design. In P. Stecker, The Fashion Design Manual (pp. 41-54). South Yarra: Macmillan Education Australia PTY LTD. 1999.

[14] E. Nawawi, Interview to a fashion designer in Surabaya. (L Renaningtyas, Interviewer) Surabaya, Siwalankerto. 2019. 